\title{
Paper Toys as Paikem Media to Introduce Local Character for Elementary School-Age Children
}

\author{
$1^{\text {st }}$ ErciliaRini Octavia \\ Faculty of Fine Art and Design, \\ Sebelas Maret University, Indonesia \\ $\underline{\text { erciliaoctavia@staff.uns.ac.id }}$
}

\author{
$2^{\text {nd }}$ Anugrah Irfan Ismail \\ Faculty of Fine Art and Design, \\ Sebelas Maret University, Indonesia \\ irfaniax@staff.uns.ac.id
}

\begin{abstract}
The objective of research was to describe the use of Pandawapaper toysas the implementation of PAIKEM (Pembelajaran Aktif, Inovatif, Kreatif, EfektifdanMenyenangkan) (English: Active, Innovative, Creative, Effective and Joyful Learning) media in introducing local character for establishing positive personality values to Elementary School-age children in Surakarta City and to improve Elementary School-age children's understanding on Pandawa local character. The research method employed was action research design. The subject of research was students of SekolahDasarMuhammadiyah 1 Ketelan Surakarta (the $1^{\text {st }}$ Muhammadiyah Elementary School of Ketelan, Surakarta). This research employed subjective test, interview, and observation as the techniques of collecting data. The observation data was obtained by means of collecting data during learning process to find out the students' activity in organizing Pandawa paper toys pattern grids, observing and listening to class teacher and author's explanation, and students' story telling about Pandawa character by means of presentation before the class. Data analysis was carried out using qualitative analysis, consisting of data reduction, (2) data display, and (3) conclusion/verification. From the result of data analysis, the following conclusions could be drawn. (1) Elementary School-age students can identify Pandawa character by means of organizing paper toys pattern grid into 3D Pandawa visualpaper toys. Thereafter, the students listened to the class teacher and author's explanation about Pandawa character. Teacher and author's explanation was given using Pandawa paper toys as visual aid to delivery message; then evaluation was conducted to find out whether or notthe use of paper toyswas effective in introducing Pandawa local character to Elementary School students by means of (2) students retelling the Pandawa character through presentation before the class. Most students could retell well the names and characters of Pandawa with paper toys visual aid. It is because the paper toys figure created visualized physical characters and weapons of individual Pandawa characters, thereby it was easy to identify and to remember the description of their character.
\end{abstract}

\section{Keywords - paper toys, PAIKEM, local character}

\section{INTRODUCTION}

Elementary school age is categorized as the end of childhood in which main development occurs, particularly socialization establishment or called in- group age. Children's tissue number growth will be affected by experience the children get in their early life, particularly joyful experiences. Therefore, the creation of children personality should be arranged in this period, as it is the underlying period to develop cognitive, motor, and emotional abilities of child (YulianiNuraniSujiono, 2009: 7).The development of children thinking ability will determine their ability of understanding environment both logically and realistically. Then, the more developing the children's cognitive ability and understanding on object, people, and event in their environment, the more accurate is the children's assessment. Elementary School-age children have begun to use adequate logic, so that in this age, they have been able to distinguish good things from the bad ones (Elizabeth, 1993: 54). In the term of motor development, children in this age love repetition, in which they are available to repeat an action until their muscle pattern is practiced to do it effectively. Children tend to try something more bravely as well than they in adulthood. It grows motivation to learn. Emotion of children in this age is dependent on maturation and learning factors all at once, but it can also be dependent on one of the two factors. Emotional reaction not arising in early life cannot be said as inexistent. Emotional reaction will likely arise later along the learning the children acquire from their environment. Positive control over learning pattern serves as a preventive measure, because the learning they receive in this age is the key to creating their personality in adulthood later (Elizabeth, 1978: 210-214). It can be concluded that Elementary School age is considered as a sensitive period to children development, in which physicalmotor, social, and emotional functions need stimulation. Recalling the urgency of children development in this age, the creation of personality with positive values should be implemented.

The creation of personality in Elementary School age can start with introducing first the positive values prevailing in local community, the area where they live. It is also true for the Elementary School-age children living in Surakarta City, in which there are some positive values as the implementation of Javanese local culture wisdom that can be introduced to Elementary School age children: kindness, prudence, honesty, loyalty to religion tenet, bravery, 
tenacity, decorum, gentleness, trusteeship, and reciprocity. This value introduction is important to make the children behave according to the mores existing in living within society during adulthood. The inculcation of positive values can be done by adapting local character from archipelago culture heritage, such as character in puppetry (pewayangan). Wayang (puppet) is recognized as amasterpiece as it has noble values for human civilization. It is in line with Burhan Nurgiyantoro (2011) "WayangdanPengembanganKarakterBangsa" writing that puppet is replete with values, reflected on character of figure, story, and some other elements supporting, so that wayang is feasible to be a reference in creating the nation's character. Because of being replete with values as well, on November 7, 2003, UNESCO as UN's organization for world culture stipulated wayangkulit (leather puppet) as the manifestation of puppet shadow performing art coming from Indonesia, the world's Masterpiece of Oral and Intangible Heritage of Humanity. Local character of pewayangan figures often adapted in delivering message about positive values is Pandawa figure. Pandawa figures (Yudhistira, Bima, Arjuna, Nakula, and Sadewa) are considered as capable of representing kindness values such as honesty, sincerity, policy, nobleness, bravery, and persistence.

The delivery of message adapting Pandawa local character to build positive personality can be done through media preferred by and representative to Elementary School-age children, that is, using PAIKEM (PembelajaranAktif, Inovatif, Kreatif, EfektifdanMenyenangkan) media. PAIKEM is a teaching approach using appropriate learning method and teaching media along with environment arrangement in such a way that learning process becomes active, innovative, creative, effective and joyful. PAIKEM also enables the students to do diverse activities to develop character in behaving, developing understanding, and their own skill correctly and responsibly (UmiKulsum, 2011: 57). One implementation of PAIKEM media considered as representative to introduce Pandawa local character to Elementary School children in Surakarta City is paper toys. Paper toy is one of paper craft categories, an art of producing a paper-based object, by means of cutting, folding, and pasting the pattern designed in such a way that can create the desired shape. Paper toy resembles origami, but the objects produced by paper toy resemble the original shape more than the origami does.

replika45.blogspot.co.id/2012/09/pengertian-

(http://paper-

papercraft.html). Paper toysas visual aid to deliver message is visualized consistent with the shape preferred by Elementary School-age children. This study using classroom action research approach and qualitative analysis is expected to (1) describe the use of Pandawa paper toys as the implementation of PAIKEM media in introducing local character to create personality of positive values to Elementary School-age children in Surakarta City and (2) improve the Elementary School-age children's understanding on Pandawa local character. Meanwhile, to describe the use of Paper Toy as PAIKEM media in introducing local character to Elementary School-age children and to improve the understanding on Pandawalocal character, this study was conducted in SekolahDasarMuhammadiyah 1 Ketelan Surakarta.

\section{METHOD}

This study was a Classroom Action Research. Classroom action research is a practical research intended to improve the quality of learning in the class and the corrective action (measure) taken to find answer to the problem raised from daily activities in the class (Kasbolah, 2001). Then, the model employed in this classroom action research was selfreflection spiral system developed by Kemmis and Taggart (1990). In their planning, Kemmis and Taggart employed self-reflection spiral system, each cycle of which included planning, acting, observing, and reflecting, explained as follows. (1) Draft, before conducting a research, the author formulated problem statement, objective, and action plan including research instrument and learning design; (2) Activity and observation included the action taken by authors as the attempt of constructing students' conception (understanding) and observing the result or effect of learning model application; (3). Reflection, the author studied, saw, and considered the result or the effect of action taken based on observation sheet filled in by observer; and (4) Revised plan, based on the result of reflection, the observer developed a plan considering the revised plan for the $\mathrm{n}$ ext cycle. The procedure of classroom action research with Kemmis' reflection spiral system is illustrated in the figure below.

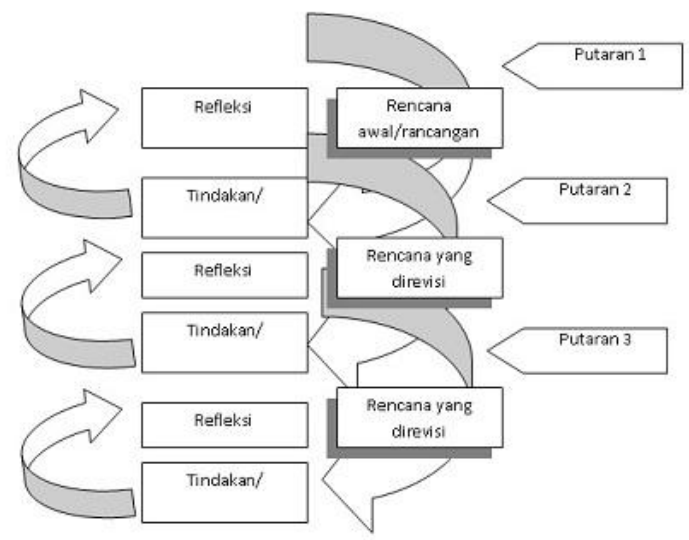

Figure 1. The Procedure of Classroom Action Research using Kemmis\& Taggart's Spiral Model

This classroom action research was taken place in the $1^{\text {st }} \mathrm{C}$ grade of SekolahDasarMuhammadiyah 1 Ketelan Surakarta consisting of 36 students and assumed by 2 class teachers and 4 apprentice teachers. This research was conducted for a half of semester (3 months) from February to April 2018. The subject of research was all of the $1^{\text {st }} \mathrm{C}$ graders and 
the class teachers. The data of research included data of planning, implementation and evaluation in the process of introducingPandawa local character to Elementary School age children. The instruments of collecting data used in this study were field note, (b) evaluation in the form of introducing and describing again thecharacter of Pandawa figures. In this case, the author served as main instrument having abilities of selecting, assessing, concluding, and deciding the data (Moleong, 1989). Techniques of collecting data used in this research were observation and subjective test in the form of introducing and describing again the character of Pandawa figures. This assignment is given to every students by telling them to identify the five Pandawa paper toys and to retell (to describe) them before the class. Observation was conducted during learning process to find out the students' activity in organizing paper toys pattern of Pandawa character completed with weapon attribute they wear (designed by the author) thereby creating a standing table/floor paper-toys as the Pandawa figure that can be played or displayed. Through the figures the students have organized, they will recognize Pandawa consisting of five characters:Yudhistira, Bima, Arjuna, Nakula, and Sadewa. Then, by showing off the figures of Pandawa one by one, the class teacher tried to describe individual characters of Pandawa to all students in the class. Furthermore, test technique was implemented to the students by means of introducing and describing again the character of Pandawa figure before the class (presentation). Data validation was carried out using triangulation technique. Data analysis was carried out using qualitative analysis involving three activities at the same time continuously and after data collection: (1) data reduction; (2) data display; and (3) conclusion/verification.

The indicator of performance in this research was the description of clue or sign expected resulting as the form of successful action taking. The outcome generally targeted to be performance indicator in this study was that Elementary School students can identify the character of pandawa local figures, can distinguish individual figures such as Yudhistira, Bima, Arjuna, Nakula, or Sadewa, through their physical characterand weapon inherent to individual figures. Furthermore, the students began to identify and to understand individual characters of Yudhistira, Bima, Arjuna, Nakula, or Sadewareplete with local cultural wisdom values such as kindness, prudence, honesty, loyalty to religion tenet, bravery, tenacity, decorum, gentleness, trusteeship, and reciprocity. Through the introduction and understanding, Elementary School students can love and adopt positive characters from Pandawa local character and bring them until adult, to be a person with good character. Having organized and using paper toys media for learning Pandawa character, the students were tested to retell it. This Classroom Action Research with Kemmis and Mc. Taggart's model was conducted continuously and sustainably/spirally thereby finding the optimum result. In practice, this action had been conducted by class teacher and author. The implementation of action consistent with the research plan was as follows: (1) students organize pattern into Pandawapaper toy figures in order to identify the character of Pandawa figures and listen to teacher and author's explanation about Pandawa character through paper toys media; and (2) students retell the character of Pandawa through presentation before the class.

\section{DISCUSSION}

\section{Action 1}

In the attempt creating personality, the positive values applied to Elementary School-age children in this research are: kindness, prudence, honesty, loyalty to religion tenet, bravery, tenacity, decorum, gentleness, trusteeship, and reciprocity. The introduction of values adaptslocal character from archipelago culture heritage, Pandawa figures with paper toys media. This media is an Active, Innovative, Creative, Effective, and Joyful Learning media (Indonesian: PAIKEM). This activity of introducing Pandawa character started with distributing A3 paper equipped with Pandawa grid (pattern) by class teacher and author to all students in the class. Pandawa characters are designed by the author in such a way that its visual appearance (color, figure, outline, and 3D appearance) is adjusted with motor ability and absorbability of Elementary School students. Pandawa figures' faces are designed to be friendly and funny.

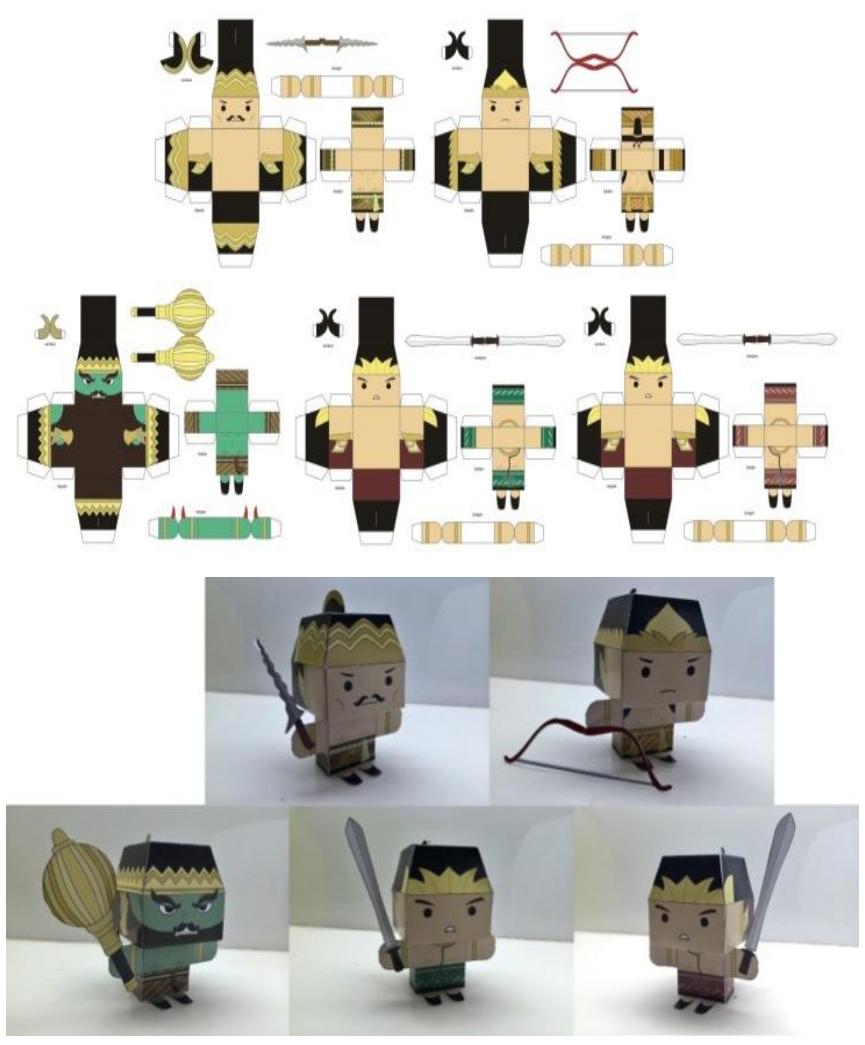

Figure 2. Grid and finished work of Pandawa paper toys 
All of students are directed to try observing Pandawa paper toys pattern grid, considering any gaman (weapon) and physical characteristic of individual figures such as Yudhistira, Bima, Arjuna, Nakula, and Sadewa. Then, they cut and paste every corner of paper hook to create Pandawa papertoys. This creative activity is joyful because they consider that cutting, arranging, and pasting are the part of playing although they actually begin to learn the characteristics of Pandawa figures. It is in line with Piaget (2010) stating that intellectual development of Elementary School-age children should be supported by fertile environment created deliberately to growth their potency optimally, among others, by means of playing circumstance/environment (https://mitaelmi.wordpress.com/2012/12/21/aspekperkembangan-kognitif-anak-usia-sekolah-dasar/).

So far, in this class action process, the students recognize Pandawa charactersonly with physical characteristics and the weapon equip them: (1) Yudhistira has jamuskalimasada, tunggulnaga, and robyongmustikawarihweapons as visualized with kris in paper toys; (2) Bima has godhorujakpolo, kuku pancakenaka, alugara, bargawa, and bargawasta weapons visualized with palugada in its paper toy; (3) Arjuna has pasupati and gendiwaweapons visualized with bow and arrow ion its paper toy: (4) Nakula has tirtamanik sword weapon visualized using sword in its paper toy; and (5) Sadewa has also tirtamanik sword weapon visualized with sword in its paper toy. Each of students can rematch appropriately Pandawa figures and their respective weapon.

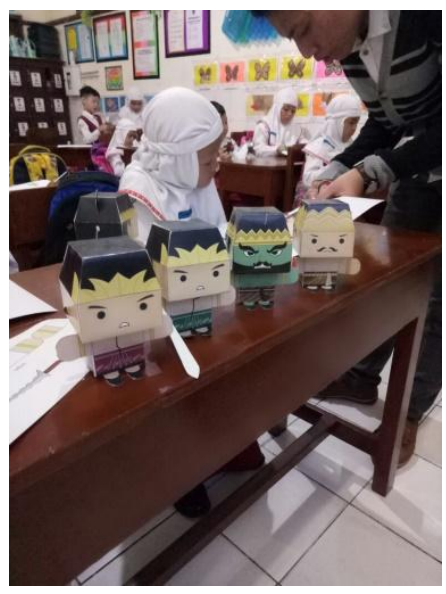

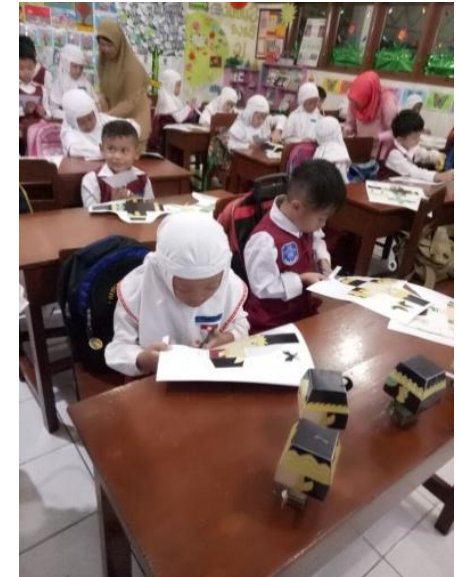

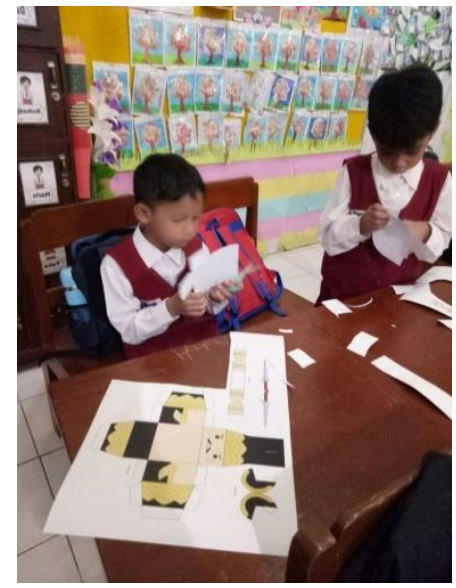

Figure 3. Process of organizing Pandawa paper toys

In the next stage, class teacher and author tells about Mahabharata war in which Pandawa is protagonist character defending the truth in the story. Then, teacher and author explain about positive values the Pandawa figures have through paper toys media. Every Pandawa paper toys character is made the model to describe good characterthat can be imitated by students. Meanwhile, the characters of individualPandawa figures are as follows:

1. Yudhistira has very wise character, has no enemy and has never lied during his life, has high moral, loves to forgive and always remit the helpless and surrendering enemy. In addition, Yudhistira also hasother characteristics such as just, honest, patient, self-confident, and loyal to religion tenet.

2. Bima is as very strong pendekar (master of fighting), has long arm, tall and big body, and spookiest face compared with his brothers. He has tenacious, brave, resolute, honest, straightforward, and gentle dispositions and he has never eaten his words.

3. Arjuna has archery skill and is called as the best knight who is smart, bright, quiet, gentle, decorous, brave, and loving to help the weak people, and Arjuna is surely very handsome and muscular. 
4. Nakula is honest, loyal, obedient to parents, reciprocal, and cankeep the secret.

5. Sadewa is obedient to parents, honest, loyal, reciprocal, and can keep the secret.
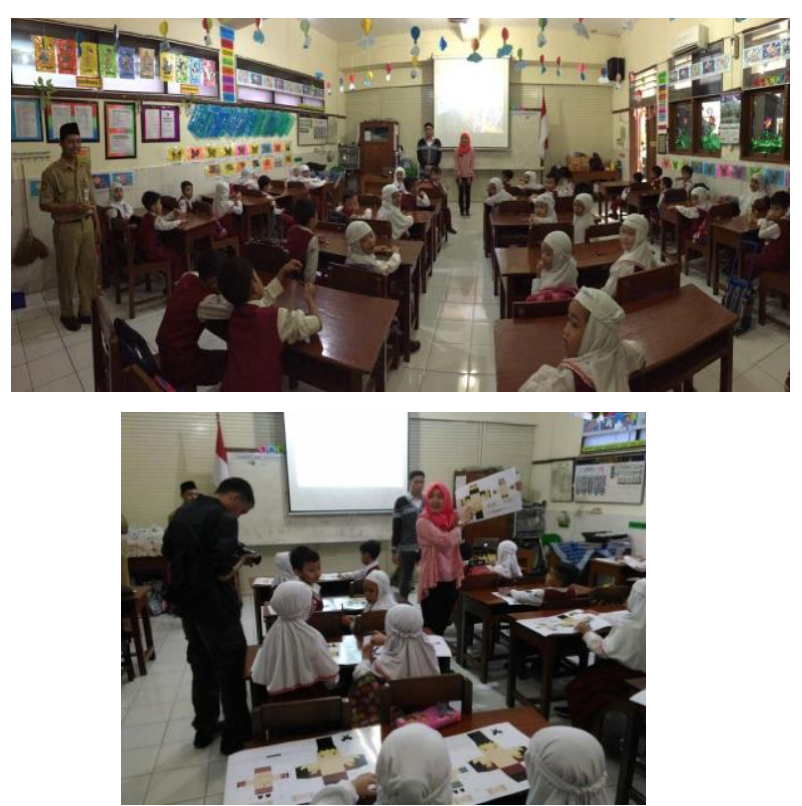

Figure 4. The author tells about Pandawa characters in detail through paper toys as the learning media.

In this stage, students listen to and observe any description given by class teacher and author through paper toys. The story about the character of Pandawa characteristics contains positive educating moral message; thus, it is unsurprising that the students are provoked to follow or to imitate Pandawa behavior concerning positive values such as kindness, prudence, honesty, loyalty to religion tenet, bravery, tenacity, decorum, gentleness, trusteeship, and reciprocity. A two-way interaction is made in this stage as well, by involving students, in which when class teacher and author tell story, the students are asked for their opinion on the character of individual Pandawa figures. Students sometimes are asked whether or not they have characteristics like Pandawa. Through storytelling using paper toys media and active interaction with students, they seem to enjoy and to pay attention to class teacher and author's explanation about Pandawa figures' behavior that can be imitated by students.

\section{Action 2}

In this stage, every student is told to retell the character of figure inherent to Yudhistira, Bima, Arjuna, Nakula, and Sadewa, to represent it before the class by carryingPandawa paper toys as visual aid to recall the characters of Yudhistira, Bima, Arjuna, Nakula, andSadewa that have been explained by class teacher and author previously. The sequence of presentation in this class is made by preparing rolled papers containing the names of students in a class to be shaken and drawn. Therefore, the one whose name gets out should come to the front bravely to retell what class teacher and author have told. This action is a review on learning that has been done previously, after the studentsarrange Pandawa paper toys and listen to class teacher and author's explanation. Review is to paraphrase any things learnt before, and is the form of learning activity involving more cognitive aspect of students (Yoapkinand Simpson, inMunandir,1987: 37). Review is called as a skill to collect, to use, and to recall information consisting of attention, organization, review and retention. One review in this classroom action research is conducted by students who retell the character of Pandawa figure. "Retelling" is a techniqueof facilitating the students in their learning; so that this studyis related to all components of instructional system. Retelling learning model is actually a subchapter of "speaking" learning model in Indonesian language subject and the continuation of "continuing the story" learning model. It means that, after the students master the "continuing the story" learning, they will go up tothe "retelling" learning model. In retelling the character of Pandawa figures, the students have begun to learn ordering words and sentence independently, despite simple way. In this stage, the author observes and evaluates the effectiveness of paper toys use as visual aid of retelling Pandawa character. Most students can retell well the name and character inherent to Pandawa with paper toys visual aid. It is because paper toys figure created visualized physical characters and weapons of individual Pandawa characters, thereby it was easy to identify and to remember the description of their character. Meanwhile, when the presentation is made without paper toys, the students are less capable of describing the characters of Pandawa figure completely. The constraint encountered during presentation without Pandawa paper toys is, among others, forgetting to mention the Pandawa character or exchanging the character of Nakula with that of Sadewa. The presence of paper toys media helps the students retelling Pandawa character for some reasons.

1. It increases self-confidence and reduce shy/awkward feeling during standing before the class because students feel being accompanied with paper toys, a joyful toy.

2. It minimizes bottleneck or word/sentence depletion because when the students forget the character of Pandawa, they will remember it again when seeing the paper toys in their hand (recalling Pandawa paper toys visualized completely with physical characteristics and weapon of individual figures).

3. It minimizes word repetitions, because when retelling the characterof Pandawa, the students employ paper toys visual aid and order the Pandawa figures according to their kinship order from the oldest to the youngest (from Yudhistira to Sadewa). 

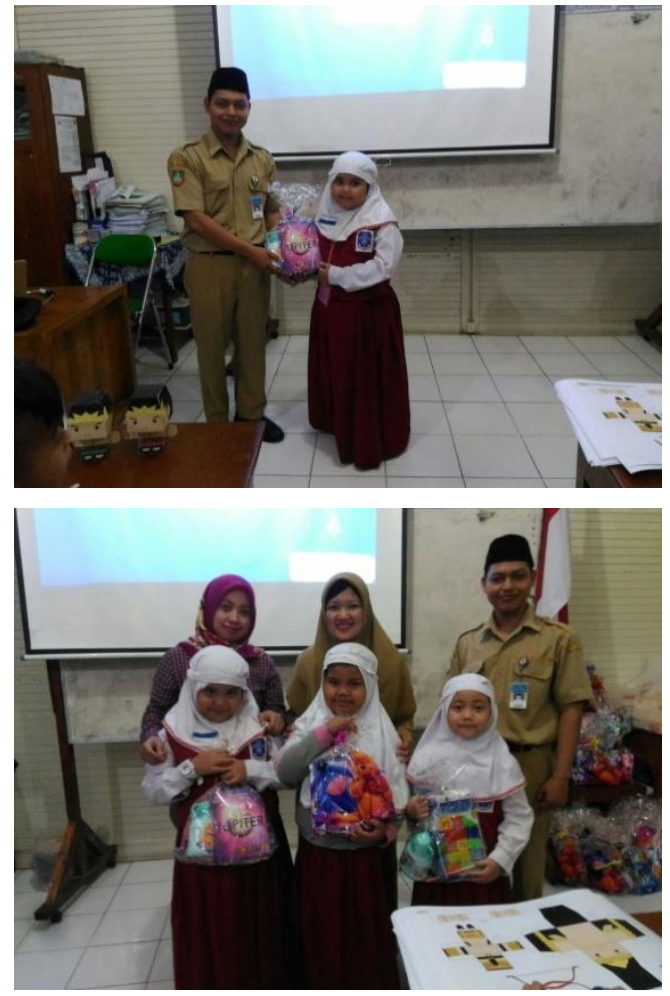

Figure5. Students who can retell the Character of Pandawa in detail will be rewarded

\section{CONCLUSION}

Considering the result of research above, it can be concluded that (1) Elementary School age-students can identify the character of Pandawa figures started with arranging paper toys pattern grid until creating Pandawa visual 3D paper toys. Thereafter, the students listen to class teacher' and author'sexplanation about the character of Pandawa figures(Yudhistira, Bima, Arjuna, Nakula, orSadewa) replete withkindness, prudence, honesty, loyalty to religion tenet, bravery, tenacity, decorum, gentleness, trusteeship, and reciprocity values. Teacher and author's explanation was given using Pandawa paper toys as visual aid to delivery message; then evaluation was conducted to find out whether or not the use of paper toys was effective in introducing Pandawa local character to Elementary School students by means of (2) students retelling the Pandawa character through presentation before the class. Most students could retell well the names and characters of Pandawa with paper toys visual aid. It is because the paper toys figure created visualized physical characters and weapons of individual Pandawa characters, thereby it was easy to identify and to remember the description of their character.Thus, paper toys can be used as Active, Innovative, Creative, Effective, and Joyful learningto introduce local character in Elementary School-age children.

\section{REFERENCES}

[1] Hardianto, D. 2005. Media Pendidikan sebagai Sarana Pembelajaran yang Efektif, Majalah Ilmiah Pembelajaran 1, Volume 1., Hal. 95-104.

[2] Hurlock, Elizabeth B., PsikologiPerkembangan: SuatuPendekatanSepanjangRentangKehidupan, Erlangga, Jakarta, 1993.

[3] Kasbolah, K. 2001. Penelitian Tindakan Kelas. Malang: Penerbit Universitas Negeri Malang

[4] Kemmis, S. \& Taggart, R.B. 1990. The Action Research Planner. Third Edition. Victoria: Deakin University

[5] Miles, M.B. \& Huberman, A.M. 1992. Qualitative Data Analysis. Baverly Hills: Sage Publisher

[6] Moleong, L.J. 1989. Metode Penelitianm Kualitatif. Bandung: Remaja Karya.

[7] Munandir. 1987.Rancangan Sistem Pengajaran. Jakarta: DepartemenPendidikandan KebudayaanDirektoratJendralPendidikanTtinggi

[8] Piaget, Jean, Antara Tindakandan Pikiran, disuntingolehAgusCremers, PT. Gramedia, Jakarta, 1988.

[9] Piaget, Jean, \&BarbelInhelder, PsikologiAnak, Terj. Miftahul Jannah, PustakaPelajar, Yogyakarta, Cet. 1, 2010.

[10] Sujiono, Yuliani Nurani. 2009. Konsep Dasar Pendidikan Anak Usia Dini. Jakarta: PT. Indeks.

[11] Umi Kulsum, Implementasi Pendidikan Karakter Berbasis PAIKEM, (Surabaya: GemaPratama Pustaka, 2011), cet.ke-1, h. 57

[12] https://pasberita.com/kisah-dan-karakter-pandawalima/, Aprina Sara, MengenalKarakterdanKisahPandawa Lima yang HebatdanGagah Perkasa, posted January 8, 2018

[13] https://journal.uny.ac.id/index.php/jpka/article/view/131 4/1092, Burhan Nurgiyantoro, Wayang dan Pengembangan Karakter Bangsa, FBS Universitas Negeri Yogyakarta: JurnalPendidikan Karakter, Tahun I, Nomor 1, Oktober 2011

[14] https://www.halopsikolog.com/ciri-ciri-perkembangankognitif-peserta-didik-usia-sekolah-dasar/355/\#respond Bambang Sumasono, TahapdanCiriCiriPerkembanganKognitifPesertaDidikUsiaSekola hDasar, posted February 18, 2017

[15] https://mitaelmi.wordpress.com/2012/12/21/aspekperkembangan-kognitif-anak-usia-sekolah-dasar/, Aspek Perkembangan Kognitif Anak Usia Sekolah Dasar

[16] https://hardiyansyah11.wordpress.com/2015/06/26/perk embangan-fisik-motorik-pada-anak-sd-7-12-tahun/, Hardiyansyah11, Perkembangan Fisik Motorik Pada Anak SD (7-12 Tahun), posted June 26, 2015 